\title{
The Impact of Access to Microcredit Programme on Women Empowerment: A Case Study of Cowries Microfinance Bank in Lagos State, Nigeria
}

\author{
Adijat Olubukola Olateju \\ Faculty of Social Sciences, Department of Economics, \\ Lagos State University, Ojo, Lagos, Nigeria
}

Doi: 10.19044/elp.v5no2a2

URL:http://dx.doi.org/10.19044/elp.v5no2a2

\begin{abstract}
Women empowerment is an essential developmental tool in every economy especially in less developed countries, as it helps to enhance women's socio-economic well-being. Empirical evidence has shown that microcredit is an effective tool in enhancing women empowerment, especially in developing countries. This paper, therefore, investigates the impact of microcredit programme on women empowerment in Lagos State, Nigeria. The study used Cowries Microfinance Bank (CMB) as a case study and a total of 359 women entrepreneurs were selected by simple random sampling technique from the list of Cowries Microfinance Bank's customer. Selection bias which could arise from non-random selection of participants or nonrandom placement of programme was adjusted for by dividing the sample into participant women entrepreneurs and non-participant women entrepreneurs. The data obtained were analyzed with Propensity Score Matching (PSM) technique. However, unlike most findings in the literature, the result of the Average Treatment Effect on the Treated (ATT) obtained from the PSM indicates that the credit programme has a significant effect on the empowerment of women in the study area. It is therefore, recommended that microfinance banks should be encouraged to give loan to women and for more impact of the loan to be felt by the beneficiaries, the loan programme should be complemented with other programmes such as training, grant, and periodic monitoring of the business of the recipients of the programme.
\end{abstract}

Keywords: Empowerment, Microcredit, Social, Economic, Political, Development

\section{Introduction}

Women are more vulnerable to poverty than their male counterpart most especially in developing countries like Nigeria where gender stereotype 
is high. In spite of Nigeria's enormous resources the country still ranks 152 out of 188 countries according to the report on Human Development Index. (HDI) (Olawoyin, 2017). Also, almost $80 \%$ of her population is living in abject poverty from this figure; more than half were women (60\%) (Gender in Nigeria Report, 2012). In Nigeria, women are more vulnerable to poverty; because they are often limited in their ability to securing white collar jobs due to their reproductive role, domestic role, cultural stereotype which in most cases put women at disadvantage when compare to their male counterpart.

However, in spite of these obstacles the role of women in development and in ensuring sustainable development cannot be overemphasized. Given the vital roles played by women in the economy and also to ensure inclusive growth, women need to be empowered. For instance, it has been emphasised that investing on women is an avenue to sustainable peace in DR Congo and Nigeria (Alliance for Financial Inclusion (AFI), 2014).

Women empowerment can transpires in different dimensions such as economic, social, cultural, moral, legal, political, etc. (Malhotra, Schiler \& Doender 2002). It has been observed that women position in the society is of paramount importance as it has a direct and high relationship with economic development (Duflo 2012, Doep, Tertill and Voenna, 2012). Empowering women is not only an essential developmental policy, but it can also help to enhance economic growth (Doepke \& Tertilt, 2014).

Entrepreneurship development which is an economic dimension of women empowerment is vital and to empower women in this area, capital is imperative. Capital can come in the form of personal efforts, grant, formal financing or informal financing. However, getting access to capital through formal funding in the form of loan is often difficult due to some stringent requirements imposed by some conventional banks, money lenders, etc.

Given the important role played by women in economic development, coupled with their contributory role in the family, various governments in Nigeria have embarked on many developmental programmes both in the past and in the present time in order to empower and better the lives of women. Some of these developmental programmes used in the past are Family Support Programme (FSP), Better Life for Rural Women (BLRW), National Economic and Empowerment Development Strategy (NEEDS), etc.

In addition, based on the resolution at the United Nations in 2005 on the need to eradicate poverty especially in less developed countries, this made the Nigeria government to focus on microfinance programme as a developmental tool that can help to alleviate poverty, especially among women. To complement these efforts in recent time, and to ensure the continuation of the programme of past administration, the current government has implemented the Micro Small and Medium Enterprises Development (MSMED) fund which was introduced in 2014 with a share capital of N220 
billion, from this fund, microfinance banks are required to lend $60 \%$ of this fund to women.

Furthermore, other intervention funds were introduced recently to boost women empowerment by the government; these are the N140 billion Federal Government Enterprises Empowerment Programme (GEEP) and the N1.6 billion National Women Empowerment Fund (NAWEF) that is set aside from the GEEP fund exclusively for women (Kolawole, 2017). To complement these, an individual initiative was introduced in the name of Aliko Dangote foundation, which is a private initiative that involves the injection of N10 billion to Alleviate the poverty of some one million women known as Dangote Foundation micro-grants programme which aims at providing cash transfer to selected poor and vulnerable women and youths in the society (Okoro, 2016).

However, among the developmental programmes introduced by the government, more attention has been placed on microfinance as a source of providing finance for entrepreneurs most especially women, and also due to the fact that majority of the clients of microfinance are often women.

In Nigeria, given the high population of women with majority of them in poverty and they often participate more in microcredit programme than their male counterpart; there is a need to assess the impact of microcredit on women empowerment. The study will also help to determine whether to put in more efforts on the policies that are on the ground or to make some adjustment on the available policy so as to ensure that the right and effective programmes are used.

Results from studies on the impact of microcredit on women empowerment are mixed as some studies found a negative impact of microcredit on women empowerment while some found a positive effect of access to microcredit loan on women empowerment. This study will add to the existing literature by examining the impact of microcredit on women empowerment in Lagos State, Nigeria using Cowries Microfinance Bank (CMB) as a case study bank. Therefore, the objective of this study is to examine if microcredit given to women in the study area has an impact on women economic development in terms of empowerment.

Given the introductory part of this paper, the rest of this paper is divided into four parts. Part two provides the literature review on women empowerment. Part three, indicates the methodology employed by the study. Part four presents the result and discusses the findings from the result. Finally, Part five gives the conclusion, recommendation/policy implications, and some suggestions for further Study.

\section{Literature Review}

Some studies have shown the significance impact of access to microcredit on women empowerment. For instance, Hashimi, Schuer, and 
Relay (1996) in their study of Grameen Bank and the Bangladesh Rural Advancement Committee (BRAC) credit product, found that the two programmes have a significant impact on all the eight indices used in measuring empowerment. Also, in Pitt, Khandker, and Jennifer (2006) the authors found that access to microcredit by women has increased their empowerment.

A Correlation relationship was found between access to microcredit programme and women empowerment, for instance, Yogendrarajah (2011) study showed a direct correlation between micro-credit and empowerment. In the same vein, a correlation relationship was also found between microlending and empowerment (Ndubi, 2008). Nessa, Ali, and Abdul-Hakim (2012) found a high positive impact on women empowerment through participation in microcredit programme.

Habib and Jubb (2012) examined the socio-political empowerment and social participation of women. The study opined that microcredit is an important development programme that has helped to enhance women empowerment. Mamin (2013) used anecdotal evidence and was able to conclude that microcredit has a high impact on women empowerment. However, the author cautioned that for the programme to be effective welfare microcredit approach and not commercial microcredit approach should be used. Also, the author further explained that the approach should be accompanied by frequent counseling. Chowdhury (2013) in his study in Bangladesh found a strong evidence of participation in microfinance programmes on women empowerment. The author, however, emphasized that microfinance programme should be mixed with other programmes to achieve an effective impact.

Some studies conducted in Africa on women empowerment also show a significant and positive impact of access to microcredit on women empowerment. For example, in a research conducted in the two suburb areas of Accra, Ghana the author employed the contraceptive use by women as a measure of women empowerment, the study found that access to microfinance credit has helped women to improve their contraceptive use (Norwood. 2011). Oladejo (2014) opined that participation in microfinance programmed had a significant impact on the household well being, income, job creation, and women empowerment. Although, the author identified and stressed the need for a reduction in the interest rate as reacted by the respondents

Idris and Agbim (2015) in a study conducted in Nasarawa State, Nigeria found a significant impact of microcredit on economic empowerment. Arora and Meenu (2010) emphasised that the provision of financial and nonfinancial assistance to women entrepreneurs due to an increased in the number of microfinance programmes had enhanced their empowerment. 
Similarly, Jack and Roland (2016) in a study in Yenogoa, Bayelsa State, Nigeria found that due to financial and cultural constraints market women in the study area were impeded in their entrepreneurial development which had in turn negatively affected their economic empowerment. The authors, therefore, concluded that with access to finance women empowerment in the study area will be improved.

However, in spite of the support for microfinance as a tools for women empowerment some studies (Seta, 2014; Ngo and Wahha, (2012); Hashimi, (2012); Kabeer (2005);Ali and Hatta, 2012) concluded that microcredit programme like some other developmental programme cannot bring about women empowerment. Ngo and Wahha (2012) also stressed the importance of women autonomy in the control of microcredit as the study found that women who had no free control over their loan product often find it difficult to be empowered. Similarly, the study by Garikipati (2008) emphasized on the issue of patriarchy as a challenge to women empowerment which the author believed should be eradicated for women to gain ownership over an asset. In a later study by Hashimi (2012), the author gave a strong criticism that microcredit has no impact on women empowerment.

Furthermore, Seta (2014) emphasized that both the period of involvement and credit access by female do not have any significant impact on female empowerment indicators. Similarly, in a study by Kabeer (2005), it was found that participation in microcredit programme like other developmental programmes did not empower women. Also, Mukhtaer et al. (2015) in their study in Tangerang, Indonesia found a negative impact of access to microfinance programme on the lives of women entrepreneurs concerning women empowerment.

\section{Methodology}

a) Study Area

This study was conducted in Lagos State, Nigeria. The state is the largest city in African and one of the most populous states in Nigeria after Kano and Oyo State; the state is also the commercial centre of the country and has a high population density. Lagos State is also blessed with a high number of microfinance banks and microenterprises due to the high level of business activities in the state. The Cowries Microfinance Bank (CMB) which is situated in Lagos was used as the case study bank due to its collaboration with the Lagos State Microfinance Institution (LASMI) in reducing poverty especially among women and youth, coupled with its focuses on women empowerment programmes.

\section{b) Sources of Data}

The data for the study was collected through a systematic sampling from the list of CMB's clients and compose of those already taking part in the 
programme and those that are in the pipeline to participate in the programme as soon as they have completed their documentation with the bank. Therefore, 359 women entrepreneurs were selected and this consists of 183 participant women entrepreneurs and 176 non-participant women entrepreneurs.

\section{c) Model Specification and estimation technique}

The model for the impact of microcredit programm on women entrepreneurs is specified as:

Women Empowerment $=\mathrm{F}$ (Women's demography and socioeconomic characteristic, Access to microcredit;)

$$
\begin{aligned}
& \mathrm{E}=\mathrm{F}(\mathrm{C}, \mathrm{A}) \\
& \mathrm{E}=\mathrm{f}\left(\delta_{0}+\delta_{1} \mathrm{C}+\delta_{2} \mathrm{~A}+\mu\right)
\end{aligned}
$$

Where:

E represents women empowerment indicators

C represents demographic and socio-economic characteristics of women entrepreneurs

A access to credit which is equal to 1 and 0 otherwise

$\delta_{0}$ is the constant term

$\delta_{i}$ is the vector of coefficients for women entrepreneur's demographic and socio-economic characteristics

$\delta_{2}$ is the coefficient for the variable access to or no access to microcredit.

$\mu \quad$ is the error term or error committed by our regression.

The study used seven indicators to measure women empowerment and these indicators are the ability of women to (a) Make decision in the family ( b) Contribute to financial expenses in the family (c) Freedom to visit friends and make additional friends (d) Right to increase the level of their education and skills (e) Freedom to participate in workshops, seminars or other education or skills enhancement programmes (f) right to participate in politics (g) Liberty to take part in politics

To analyse the model, Propensity Score Matching (PSM) technique was used. The PSM is the conditional probability of participating in a programme given some pre-treatment characteristics of the participants. The PSM compares the effect of access to microcredit program of the participant women entrepreneurs with the non-participant women entrepreneurs (counterfactual) in the programme. The essence of propensity score matching is to match those in the treatment group with those in the control group that have the same or similar characteristic so that the self-selection bias can be eliminated. It is possible in some cases not to use all the observations in the control group. Hence, we matched the participant women entrepreneurs with the non-participant women entrepreneurs based on their propensity score 
The propensity score is calculated with a probit/logit regression. In the equation 1 below, $\mathrm{y}$ is given as the dependent variable and $\mathrm{x}$ as the independent variable. It is thus stated as:

.....Equation 1

$$
P(x)=\operatorname{Prob}(y=1 \mid x)=f(y \mid x)
$$

Where $\mathrm{x}$ is the pre-treatment characteristics of the respondents

The main focus result in PSM for an observational study is the Average Treatment Effect (ATT) because it takes care of the dissimilarities between the control and treatment group. (Becker and Ichino, 2012). Thus, the ATT is the difference between the outcome of the treated observation and the treated observation if they had not been treated.

$$
\begin{aligned}
& \mathrm{ATT}=\mathrm{E}\left(\mathrm{y}_{1} \mid \mathrm{x}, \mathrm{D}=1\right)-\mathrm{E}\left(\mathrm{y}_{0} \mid \mathrm{x}, \mathrm{D}=1\right) \\
& \text {....Equation (2) }
\end{aligned}
$$

The counterfactual is represented by the second term on the right-hand side of the equation 2; which is not observable and needs to be calculated. Therefore, in this study, $\mathrm{E}\left(\mathrm{y}_{1} \mid \mathrm{x}, \mathrm{D}=1\right)$ is the expected outcome of women entrepreneurs participating in the microcredit programme on their empowerment, while $\mathrm{E}\left(\mathrm{y}_{0} \mid \mathrm{x}, \mathrm{D}=1\right)$ is the expected outcome of participant women entrepreneurs on their empowerment given that they had not participated in the credit programme.

In the literature, some matching techniques are available such as radius matching, neighbor matching, Kernel matching etc that can be used to match the characteristic of the participants group with the non-participants group. For this study, we employed the Radius matching technique, which was used to match the characteristic of the participant women entrepreneurs with the nonparticipant women entrepreneurs on the same propensity score.

\begin{tabular}{|c|c|c|c|c|}
\hline \multirow[t]{2}{*}{ Variables } & \multicolumn{2}{|c|}{ Treated: } & \multicolumn{2}{|c|}{ Untreated: } \\
\hline & Freq & $\%$ & Freq & $\%$ \\
\hline Treat & 183 & 50.07 & 176 & 49.03 \\
\hline \multicolumn{5}{|l|}{ Marital: } \\
\hline Married & 118 & 64.48 & 105 & 59.66 \\
\hline Not married & 65 & 35.52 & 71 & 40.34 \\
\hline \multicolumn{5}{|l|}{ Mem_political: } \\
\hline political party & 127 & 69.40 & 97 & 55.11 \\
\hline $\begin{array}{l}\text { No political party } \\
\text { Education: }\end{array}$ & \multicolumn{4}{|c|}{ Education: } \\
\hline Illiterate & 20 & 10.93 & 2 & 1.14 \\
\hline Literate: & 163 & 89.07 & 174 & 98.86 \\
\hline Undergraduate & 150 & 81.97 & 140 & 79.54 \\
\hline Graduate & 13 & 7.10 & 34 & 19.32 \\
\hline \multicolumn{5}{|l|}{ Age: } \\
\hline Active working Age group & 135 & 73.77 & 153 & 89.93 \\
\hline Non-active working age group & 48 & 26.23 & 23 & 13.07 \\
\hline
\end{tabular}

\section{Result and discussion}

(a)Table1: Descriptive Statistics 
From the descriptive statistic, out of the total number of 359 women entrepreneurs, 183 (50.07) have accessed the loan facility while the remaining 176 (49.03) have not been given loan. Majority of the women entrepreneurs are married with more married women among the treated group than the untreated group. This is provided by the percentage and frequency of 118 (64.48\%) and 105 (59.66\%) respectively for the married while the percentage and frequency for unmarried are $65(35.52 \%)$ and $71(40.34 \%)$ for the treated and the untreated group respectively. Furthermore, most of the women entrepreneurs belong to a political party with more as a member of a political party among the treated group than the untreated group, and this is given by the frequency and percentage of 127 and $69.40 \%$ respectively for those that accessed the loan and 97 and $55.11 \%$ for those that have not yet accessed the loan but are slated to access the loan in the future.

Regarding education, almost 90\% (89.07) of the participant women entrepreneurs are educated and with majority falling within the range of primary school - OND education (undergraduate). This is given by a total of $81.97 \%$ which falls within the range of primary - OND education for those that have accessed the loan, while for the non-participant entrepreneurs, $98.86 \%$ are educated and $79.54 \%$ falls within the range of primary- OND (undergraduate). However, the number of illiterate for the treated which stood at $20(10.93 \%)$ outweighed the untreated which was at $2(1.14 \%)$. Majority of the women entrepreneurs for both treated and untreated are within the age group of 26-44. This indicates that most of the women entrepreneurs are still within their active working age.

\section{(b) Propensity Score Matching (PSM) - Results}

The result of the probit model indicates that almost all the variables have a significant impact on women empowerment except the variable age. The common support region is given as 1.13368517 and 0.99126545 ; this is the point where the characteristics of those involved in the credit programme matched with the characteristics of the non-participant. It is also called the overlapping region. The optimal number of block is 4 and the balancing property is satisfied at this point. This number of block ensures that the mean propensity score is not different for participants and non-participants women entrepreneurs.

Figure 1 below shows the distribution of the conditioning covariate across matched participant women entrepreneurs and the non-participant women entrepreneurs in the credit programme. The distribution indicates that the covariate did not differ across the matched participants and non-participant women entrepreneurs. 


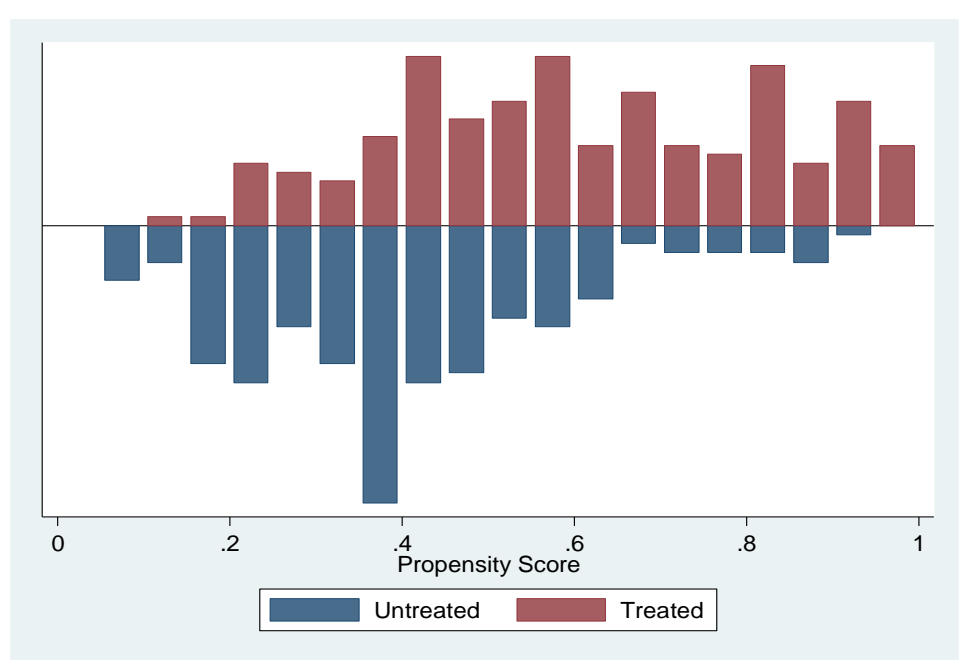

Figure 1: The Distribution of the conditioning probability

In addition, the indicator of the matching quality is also presented in Table 2; this table also helps to confirm that there are no pretreatment programme differences between those that access the microcredit and those that did not access the loan in the sample.

Table 2: The indicator of Matching Quality before and after Marching

\begin{tabular}{|l|l|l|c|}
\hline Sample & P-value & Mean bias & $\begin{array}{l}\text { Mean bias Reduction } \\
(\boldsymbol{\%})\end{array}$ \\
\hline Unmatched & 0.000 & 35.1 & \multirow{2}{*}{65.2} \\
\hline Matched & 0.208 & 12.2 & \\
\hline
\end{tabular}

This is indicated by the P-value (matched) in Table 2, Column 2 which is insignificant for the matched sample; this shows that there is no pretreatment difference between the participant women entrepreneurs and the non-participants women entrepreneurs after the match. Column 3 of the table shows a substantial drop in the mean bias of the covariate $\mathrm{X}$ after the matching has been done and this lies below the $20 \%$ suggested by Rosembaum and Rubin (1985). Besides, the mean bias reduction shows a substantial fall in the mean bias and this is indicated by $65.2 \%$ in Table 2 Column 4 above. This implies that the self-selection bias has been removed and the matching requirement has been satisfied.

Furthermore, the radius matching technique was used among other matching techniques to match the characteristics of the participant women entrepreneurs with the attributes of the non-participants ones. This matching method was used because of some advantages it has over some matching techniques (Khandker, Koolwal, \& Samad 2010). To assess the impact of microcredit programme on women empowerment propensity score matching analysis was carried out based on the use of the Average Treatment effect on 
the Treated (ATT). The result of the ATT using radius matching technique depicts that access to Cowries microcredit programme has a positive and significant impact on women empowerment in the study area. This is indicated by the estimate from the ATT result in Table 3 which indicates that those that have access to the programme have on the average a higher empowerment of 0.27 than those who did not access the program. This implies that those women entrepreneurs that participated in the credit programme are better-off regarding being empowered than those who did not participate. This is given by the magnitude of over $27 \%$ of empowerment for the women participant entrepreneurs over those non-participants ones. This result is consistent with the findings in the literature (Idris \& Agbim, 2015; Arora \& Meenu, 2010; Chowdhury, 2013) which shows that access to microcredit programme has a positive impact on women empowerment. Although, the magnitude of those that access credit over those that did not are not too high, which implies that other factors could be responsible for this, as the loan amount may be too small to bring about high impact between those who access the credit and those who did not access the loan not. Also, repayment time could be too short for the loan amount to have a huge impact on the beneficiaries. Nevertheless, the study still records a significant result of the programme on the beneficiaries in the study area.

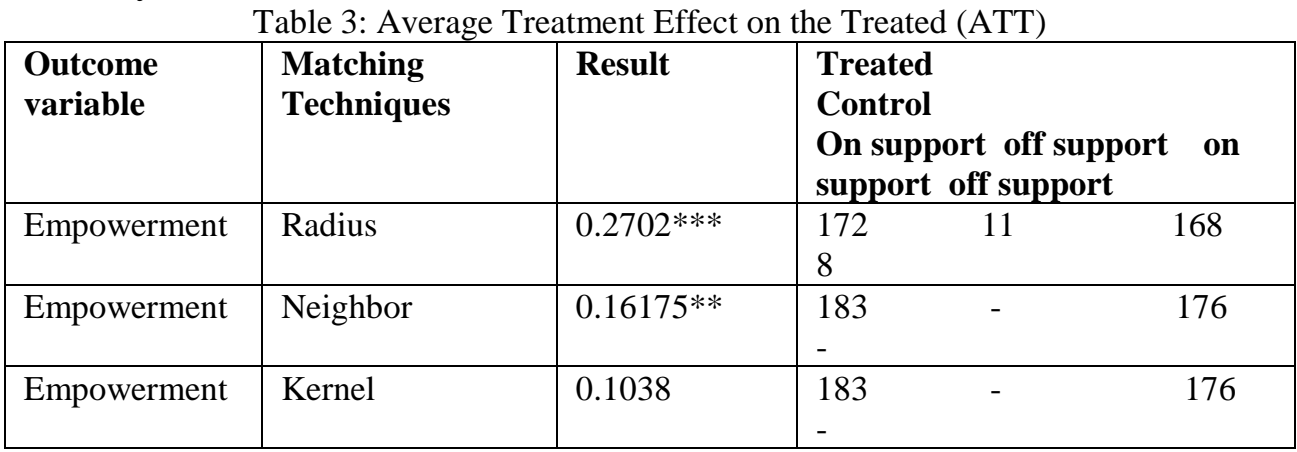

Significant level; $1 \% * * * 5 \% * * 10 \% *$

Finally, the study confirms if the radius matching result obtained in Table 1 is robust to other matching technique - Kernel and Neighbor. This was done with the use of sensitivity analysis. The results of the sensitivity analysis for Neighbor matching and Kernel matching as shown in Table 3 (Row3, and Row 4), indicate that radius matching technique is robust and consistent with the other matching technique and also higher in magnitude than Neighbor and Kernel matching techniques.

\section{Conclusion and Recommendation}

The study concludes that the credit programme by Cowries Microfinance Bank has improved the empowerment of women entrepreneurs 
in the study area. However, the impact of the microfinance programme on women empowerment is not high enough, it is therefore, recommend that the credit programme should be complemented with other programmes such as grants, training, also active monitoring of the credit should be done so as to avoid fungibility of the loan (loan used for what it is not meant for).

\section{Suggestion for further study}

Further studies can complement their assessment of the impact of the micro credit programme on women empowerment by looking at some subjective findings (anecdotal evidence) from women entrepreneurs so as to support their findings, especially in the area of empowerment that cannot be measured objectively.

\section{References:}

1. Ali, I. \& Hatta Z. A. (2012).Women's Empowerment or Disempowerment through Microfinance: Evidence from Bangladesh. Asian Social Work and Policy Review 6(2), 111-121.

2. Ali, I.. Hatta Z. A.. Azman, A., \& Islam, S,(2016). Microfinance as a Development and Poverty Alleviation Tool in Rural Bangladesh: A Critical Assessment. Asian Social Work and Policy Review 11, 4-15.

3. Alliance for Financial Inclusion(AFI) (2014). Nigeria confronts a challenging financial inclusion gender gap a case study of policy change to support women's financial inclusion. Women World Banking

4. Anju, M., Schuler, S. R., \& Carol Boender, C. (2002). Measuring Women's Empowerment as a Variable in International Development. International Center for Research on Women and the Gender and Development Group of the World Bank.

5. Arora, S., \& Meenu (2010). Microfinance Intervention- An insight into related literature with special reference to India. American Journal of Social And Management Sciences, 1(1): 44-54.

6. Arora, S. and Meenu (2012), "Microfinance interventions and customer perceptions: A study of ruralpoor in Punjab.Decision, 39(1), 62-76.

7. Awaworyi, S. (2015). Impact of Microfinance on Female Empowerment: A Review of the Empirical Literature. Contemporary Global Perspectives on Gender Economics. Information Science Reference: Unites State of America.

8. Awojobi N. L. (2014). Empowering women through micro-finance: Evidence from Nigeria Australian Journal of Business and Management Research 4(1), 17-26. | 
9. Chowdhury, M. J.(2013) Does the Participation in the Microcredit Programs Contribute to the Development of Women Entrepreneurship at the Household Level? Experience from Bangladesh. CMD Working Paper 04. Dhaka, Bangladesh.

10. Duflo, E. (2012).Women empowerment and economic development.Journal of Economic Literature, 50(4), 1051-1079. Retrived http://dx.doi.org/10.1257/jel.50.4.1051

11. Doepke M., \& Tertilt, M. (2014).Does female empowerment promote economic development? National Bureau Of Economic Research NIBER Working Paper Series 1050 Massachusetts Avenue Cambridge, MA 02138

12. Garikipati, S. (2008). The Impact of Lending to Women on Household Vulnerability and Women's Empowerment: Evidence from India, World Development, 36, 2620-2642.

13. Gender in Nigeria report (2012) British Council Nigeria UKAID.

14. Hashemi, S.M., Schuler, S.R., \& Riley, A.P. (1996). Rural credit programs and women's empowerment inBangladesh. World Development, 24 (4), 635-653.

15. Habib, M., \& Jubb, C. A. (2012). Role of Microfinance in Political Empowerment of Women: Bangladesh Experience. International Journal of Sustainable Development, 5(5), 99-110.

16. Hashemi, S.M., Schuler, S.R., \& Riley, A.P. (1996). Rural credit programs and women's empowerment inBangladesh. World Development, 24 (4), 635-653.

17. Hashmi, Taj (2012a). Microfinance and its Discontents: Women in Debt in Bangladesh by L. Karim - A Review Article. Journal of Bangladesh Studies, Special Issue: Microfinance, pp. 54-60.

18. Hashmi, Taj (2012b). Microfinance and its Discontents: Response to Munir Quddus.Journal of Bangladesh Studies, 14, (1), 53-54.

19. Idris, A. J., Agbim, K.C. (2015).Effect of social capital on poverty alleviation: A study of women entrepreneurs in Nasarawa State, Nigeria. Journal of Research in National Development, 13(1), 208-222

20. Jack, J. T., \&Roland, V.T. (2016). Access to micro credit and economicempowerment: perceptions amongst market women in Yenagoa, Bayelsa State, Nigeria. international Journal of Development and Management Review,11(1).

21. Kabeer, N. (2005). Gender equality and women's empowerment: A critical analysis of the third millennium development goal 1. Gender \& Development, 13(1), 13-24, DOI: 10.1080/13552070512331332273

22. Khandker, S. R., Koolwal, G.B., \& Samad, H. A. (2010). Handbook on impact 
23. evaluation quantitative methods and practices. Wshington, DC: The World

24. Bank.

25. Kolawole, Y. (2017, March 2). FG sets aside N112.2bn to empower micropreneurs.

Retrived: https://www.vanguardngr.com/2017/03/fg-sets-aside-n1122bn-empower-micropreneurs/

26. Mayoux, L.( 2000) Microfinance and the empowerment of women: A review of the key issues. Social Finance Unit Working Paper, 23, ILO, Geneva.

27. Mamun, C. A., Hasan, N. \& Rana, A. (2013). Microcredit and Poverty Alleviation: The Case of Bangladesh. World Journal of Social Sciences, 3(1), $102-108$.

28. Ndubi, F.D. (2008). Micro-credit scheme and women empowerment in rural communities: A case studyof Enugu North Senatorial District (Unpublished MBA Thesis). University of Port Harcourt, Port Harcourt.

29. Nessa, T., Ali. J., \& Abdul- Hakim. R. (2012). The impact of microcredit program on women empowerment: evidence from Bangladesh. International Journal of Suatainable Development, 3(9). 11-20.

30. Ngo, M., \& Wahha, Z. (2012). Microfinance and gender empowerment. Journal of Development Economics, 99(1), 1-12.

31. Norwood, C. (2011). Women, microcredit and family planning practices: A case study from rural Ghana.Journal of Asian and African Studies, 46(2), 169-183.

32. Norwood, C. (2014). Women's Empowerment and Microcredit: A Case Study from Rural Ghana J Int Stud 4, 1-22.

33. Okoro, C. (2016, October 16). Dangote Foundation multi-billion Naira micro grants Target $1 \mathrm{~m}$ vulnerablewomen.Thisday.Retrived from https://www.thisdaylive.com/index.php/2016/10/16/dangotefoundation-multi-billion-naira-micro-grants-target-1m-vulnerablewomen/

34. Olawoyin, O. (2017, April 10). Nigeria ranked 152 of 188 countries in Human Development Index.Premium Times.

35. Pakkannaa M., Arsyadb, L., \& Suryantoro, A. (2015). Economic Empowerment of Rural Women: Case Institution (MFIs) in Study of Microfinance Sociology Study, 5(11), 865-874. Tangerang, Indonesia.

36. Pitt, M., Khandker S., \& Jennifer, C. (2006). Empowering women with micro finance: evidence from Bangladesh. Economic Development and Cultural Change, 54 (4), 791-831. 
37. Peprah, J. A. (2012). Access to microcredit well-being among women entrepreneurs in MfantisimanMunicipality of Ghana. International Journal of Finance and Banking Studies, 1(1), 1-14.

38. Rosenbaum, P. R., \& Silber, J. H. (1985). Constructing a Control Group Using

39. Multivariate Matched Sampling Methods that Incorporate the Propensity

40. Score. The American Statistician, 39, 33(38).

41. Yogendrarajah, R. (2011).The Role of Micro Credit on Women Empowerment Through PovertyAlleviation, Self Employment and Health Nutrition Under Post War Development. Gumbad Business Review. 